\title{
Assessing the Effects of Engine load on Compression Ignition Engines Using Biodiesel Blends
}

\author{
Maroa Semakula \\ University of KwaZulu-Natal, \\ Department of Mechanical Engineering, Howard Campus, \\ Durban, 4041, Republic of South Africa.
}

ORCID: 0000-0002-4777-7197

\author{
Freddie L. Inambao* \\ University of KwaZulu-Natal, \\ Department of Mechanical Engineering, Howard Campus, \\ Durban, 4041, Republic of South Africa.
}

ORCID: 0000-0001-9922-5434

\begin{abstract}
This study evaluated the performance of a diesel engine operated with waste plastic biodiesel fuel blends. From the experimental data and the results obtained, at all engine loads from idling to full load the emissions of carbon monoxide $(\mathrm{CO})$, unburnt hydrocarbon (UHC) and carbon dioxide $\left(\mathrm{CO}_{2}\right)$ were low compared to conventional diesel (PD). However, the emissions of $\mathrm{NO}_{\mathrm{X}}$ were high compared to PD. The brake specific fuel consumption (BSFC) for the blends dropped while the brake thermal efficiency (BTE) increased with load for all blends until intermediate load when it decreased. WPPO blends have a higher viscosity compared to PD fuel. Compared to PD fuel, CO emissions for blend 95/WPPO5 at all engine speed idling mode were $285 \mathrm{ppm}, 298 \mathrm{ppm}, 320 \mathrm{ppm}$, and $388 \mathrm{ppm}$ while PD emissions were 270 ppm, 295 ppm, 315 ppm and 365 ppm respectively. The values for UHC for blend 95/WPPO5 at all engine speed idling modes were 35 ppm, 28 ppm, 22 ppm, and $18 \mathrm{ppm}$ compared to PD fuel with $20 \mathrm{ppm}, 25 \mathrm{ppm}, 30$ ppm, and 40 ppm respectively. The NOx emissions for PD fuel at all engine speed idling modes were 175 ppm, 225 ppm, 300 ppm and 375 ppm compared to blend 95/WPPO5 at $195 \mathrm{ppm}$, $245 \mathrm{ppm}, 335 \mathrm{ppm}$, and $397 \mathrm{ppm}$. The BSFC values for blend 95/WPPO5 at all engine idling speed modes were $0.48 \mathrm{~g} / \mathrm{kW} . \mathrm{h}$, $0.41 \mathrm{~g} / \mathrm{kW} . \mathrm{h}, 0.35 \mathrm{~g} / \mathrm{kW} . \mathrm{h}$ and $0.4 \mathrm{~g} / \mathrm{kW}$.h compared to PD at $0.45 \mathrm{~g} / \mathrm{kW} . \mathrm{h}, 0.39 \mathrm{~g} / \mathrm{kW} . \mathrm{h}, 0.33 \mathrm{~g} / \mathrm{kW} . \mathrm{h}$ and $035 \mathrm{~g} / \mathrm{kW} . \mathrm{h}$ respectively.
\end{abstract}

Keywords: Engine loads, Emissions, Higher viscosity, Spray characteristics

\section{INTRODUCTION}

The search for alternative and renewable energy has remained a persuasive concern in the last two decades with the aim of replacing depleting fossil oil. Fossil fuels have a detrimental environmental impact [1] when released to the atmosphere due to the combustion activities of fossil fuels. It is being projected that if no measures are put in place by 2030 the use of fossil fuel will raise emission levels by $39 \%$ [2]. Besides environmental concerns, fossil fuels have erratic demand and supply which increases international market prices and other commodities hence aiding in inflation [3]. Figure 1 shows measures taken to combat environmental pollution from the transportation industry in the European Union by way of taxes.

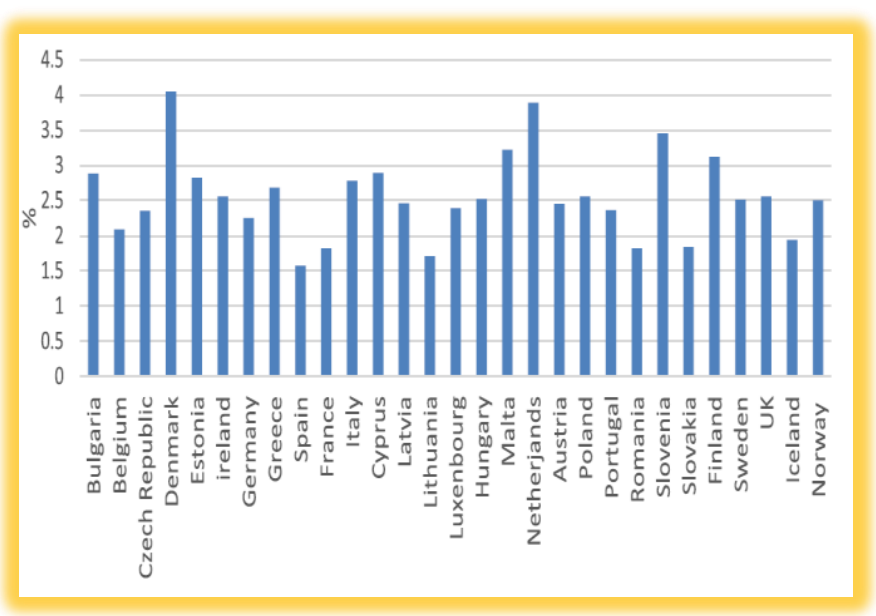

Fig. 1. Environmental taxes as \% of GDP and as \% of total taxes and social contributions [4]

Development of alternative fuel energy began in the 1900s when German engineer Rudolf Diesel invented the diesel engine using vegetable oil as fuel [5]. However, due to availability of petroleum at the time focus moved into fossil fuel to the disadvantage of bio-oil. Currently, many researchers such as [6-11] have focused on development of alternative fuel to petro-diesel. Most of this research is heavily biodiesel based as one of the solutions to replace fossil fuels while creating renewable and green fuels. Fossil fuels are non-renewable, hence depleting rapidly, which is a major reason for large-scale research to find alternative and renewable fuels. Alternative fuels must prove to be feasible, environmentally friendly and sustainable while meeting a large energy demand [12].

Biodiesel oil is known to contain physicochemical characteristics of functional petro-diesel fuel properties [13, 14]. Research has shown that biodiesel fuels have many advantages over petro-diesel fuels. For example, biodiesels are biodegradable, non-flammable, renewable, non-explosive, non-toxic and environmentally friendly $[15,16]$. These qualities show biodiesel fuels as the best option to substitute fossil fuels. Biodiesel fuels have a variety of feedstocks such as used vegetable oil, waste plastics, waste biomass, animal fats (tallow) and currently microalgae all which can be processed into biodiesel [17]. These researches have a common finding that biodiesel has the ability to be utilized as a fuel with or 
without engine modification which gives it high technical advantage $[18,19]$.

In order to determine the efficacy of biodiesel main line researchers in biodiesel fuels have evaluated engine performance using different feedstocks and different biodiesel blends [20-23]. However, few have been able to investigate the influence of load using plastic waste oil blends of biodiesel [2426]. All these researchers have concentrated on performance and emission characteristics with little attention to low load and intermediate load compared to engine full load [12, 27, 28]. For example, all low load and intermediate engine idling speeds considered as high idling increases emission from trucks and vehicles in the transport industry.

High idling or low engine loads have been shown to increase NOx emissions on roads compared to high speed road driving by a factor of $1.5[29,30]$. In other words, increasing low load increases NOX emissions [31-33]. During idling, which is low load, the fuel consumption, engine wear and maintenance increase. The average fuel consumption for example in trucks at idle is $0.8 \mathrm{~g} / \mathrm{hr}$ to $1.5 \mathrm{~g} / \mathrm{hr}$ based on the size of the engine, ambient temperature and the load of other systems such as HVAC and the vehicle's other electrical loads [34].

Driving cycle emissions of UHC are 1 to 5 times more than idling. During low, load other emissions such as CO rise to 295 $\mathrm{g} / \mathrm{hr}$ [35-37]. The carbon emissions during the driving cycles are estimated at $45 \%$ to $75 \%$, while UHC emissions during idling and low load can hit $86.4 \mathrm{~g} / \mathrm{hr}$ [34, 38]. Most diesel engines typically spend a substantial amount of time in idling mode, either on traffic stops, checkpoints or in exchange periods in fuel stations. The idle time spent varies considerably with many varied reasons to maintain engines at idle. For long haulage trucks for example the common reason is climate control, loading and offloading transport cargo or service and maintenance $[39,40]$. The other reason why trucks idle for a long time is use of the engines to heat and air condition cabs and to power amenities in the cab while on the road [41, 42].

The use of biodiesel and biodiesel blends affect diesel engine performance characteristics. Poor quality biodiesel fuel results in deposits and clogging $[43,44]$. Besides these problems use of biodiesel results in corrosion, excessive engine wear and premature engine failure [45]. Biodiesel also causes deposits in the injector pump, which interferes with the spray pattern, an essential factor in mixing fuel during the combustion process, hence poor engine performance [46]. Other demerits, which are associated with biodiesel fuel use, include dilution of lubrication oil leading to high engine oil levels, followed by loss of engine oil pressure and increased engine-bearing wear. Thus, it is clear that the quality and testing of biodiesel is an important factor in ensuring proper rating, acceptance and durability of diesel engines.

The objective of this work was to use waste plastic pyrolysis oil (WPPO) to determine the effects of idling speed load-using blends of WPPO on a diesel engine. The second objective was to study the effect of BSFC of WPPO at low and intermediate engine conditions, also known as high idling conditions. The third objective was to find the effect of engine load at high idling on engine performance and emission characteristics using WPPO as an alternative fuel.

\section{METHODOLOGY AND MATERIALS}

\subsection{Crude WPPO Oil Properties}

In this study, WPPO is selected because of the recovery of waste into energy to reduce the environmental impact of waste plastic resources. The second factor that informed the use of waste plastic is sustainability as waste plastic is readily available in plentiful supply in municipal solid waste management sites. The plastics were collected from various holding facilities within the Durban metropolitan centre with a variety of composition of plastics.

The pyrolysis oil was obtained from the pyrolysis unit designed by the Green Energy Solutions Group laboratory in the Department of Mechanical Engineering, University of KwaZulu-Natal. The author in his previous work covered the design of the unit and its performance analysis published in the proceedings of the DUE 2019 conference in Cape Town [47]. The WPPO testing and measurements were conducted at InterTek, a private Laboratory in Durban, and the results are shown in Table 1.

Table. 1. Properties of diesel, WPPO and before processing into biodiesel

\begin{tabular}{llll}
\hline Properties & Unit & PD & WPPO \\
\hline Density @ 20 ${ }^{\circ} \mathrm{C}$ & $\mathrm{Kg} / \mathrm{M} 3$ & 845 & 825 \\
K. Viscosity @ $40{ }^{\circ} \mathrm{C}$ & $\mathrm{mm}^{2} / \mathrm{s}$ & 3.04 & 2.538 \\
Cetane number & - & 55 & - \\
Flash point & ${ }^{\circ} \mathrm{C}$ & 50 & 43 \\
Fire point & ${ }^{\circ} \mathrm{C}$ & 56 & 45 \\
Carbon residue & $\%$ & 22 & 0.015 \\
Sulfur & $\%$ & $<0.028$ & 0.248 \\
Gross calories & $\mathrm{MJ} / \mathrm{kg}$ & 46.50 & 43.32 \\
\hline
\end{tabular}

\subsection{WPPO Biodiesel Processing}

A two-step process was used to process the WPPO as its acid value is higher compared to petroleum diesel. Therefore, an acid catalysed process was used with the molar ratio maintained at $12: 1\left(50 \%\right.$ v.v), $1 \%$ of $\mathrm{H}_{2} \mathrm{SO}_{4}$ was added to the preheated oil at $70{ }^{\circ} \mathrm{C}$ for $3.5 \mathrm{hrs}$ with a stirring speed of $400 \mathrm{rpm}$ in a reactor of 5 litres.

Thereafter the products were put into a separating funnel and the excess alcohol, sulphuric acid and other impurities in the upper layer were drained.

To remove methanol and water from the esterified oil a rotary evaporator was employed at $100^{\circ} \mathrm{C}$ under vacuum for $1 \mathrm{~h} 20 \mathrm{~m}$.

To complete the process reaction an alkaline catalysed process was employed by reacting the esterified oil with methanol at $6: 1$ molar ratio and $1 \%$ potassium hydroxide $(\mathrm{KOH})$ at $80{ }^{\circ} \mathrm{C}$ for $2 \mathrm{~h}$ and a stirring speed of $400 \mathrm{rpm}$.

The final step to obtain a refined biodiesel oil was to leave the produced biodiesel in a separation funnel overnight, for the 
International Journal of Engineering Research and Technology. ISSN 0974-3154, Volume 13, Number 10 (2020), pp. 2792-2802

(C) International Research Publication House. https://dx.doi.org/10.37624/IJERT/13.10.2020.2792-2802

reaction to end. This process needs $12 \mathrm{~h}$ to settle and finish reacting before the lower layer of impurities can be discarded.

\subsection{WPPO Fatty Acid Composition}

The double bond fatty acid (unsaturated), and the single bond fatty acid, (saturated), was tested using the FT-IR and confirmed by the GC-MS method. Table 2 shows the GC-MS operating conditions while Table 3 shows the FT-IR indicated compounds of pyrolysis biodiesel oil and their class compounds.

The biodiesel obtained was composed of more than 20 compounds of mixed proportion whose composition and GCMS percentage areas spectrum are in Table 4. Table 5 is a list of the test equipment utilized in the experiment.

Table. 2. Showing GC-MS operating conditions during the experiment

\begin{tabular}{ll}
\hline Property & Specification \\
\hline Carrier gas & Helium @ 23.8 psi \\
Linear velocity & $44 \mathrm{~cm} / \mathrm{s} @ 100^{\circ} \mathrm{C}$ \\
Flow rate & Air $=450 \mathrm{ml} / \mathrm{min}$ \\
& $\mathrm{H} 2=40 \mathrm{ml} / \mathrm{min}$ \\
& $\mathrm{He}=20 \mathrm{ml} / \mathrm{min}$ \\
Injector & Split injector, $50: 1$ ratio, $0.3 \mu \mathrm{L}$ injection \\
& volume \\
Temperature ramp 1 & $100{ }^{\circ} \mathrm{Chold}$ for 0 min \\
Temperature ramp 2 & $10{ }^{\circ} \mathrm{C} / \mathrm{min}$ to $250{ }^{\circ} \mathrm{C} 5$ min hold \\
Detector temperature & $250^{\circ} \mathrm{C}$ \\
Column head pressure & 23.8 \\
\hline
\end{tabular}

Table. 3. FT-IR WPPO indicated compounds of pyrolysis biodiesel oil (formulate table)

\begin{tabular}{lll}
\hline $\begin{array}{l}\text { Frequency } \\
\text { range }\left(\mathbf{c m}^{-1}\right)\end{array}$ & Group & Class compound \\
\hline $3750-3250$ & $\mathrm{O}-\mathrm{H}$ stretching & Polymeric O-H, $\mathrm{HO}_{2}$ impurities \\
$3150-2950$ & $\mathrm{C}-\mathrm{H}$ stretching & Alkanes \\
$1950-1830$ & $\mathrm{C}=\mathrm{O}$ stretching & $\begin{array}{l}\text { Ketones, aldehydes, carboxylic } \\
\text { acid }\end{array}$ \\
$1830-1725$ & $\mathrm{C} \equiv \mathrm{C}$ stretching & Alkenes \\
$1725-1575$ & $-\mathrm{NO}_{2}$ stretching & Nitrogenous compounds \\
$1575-1475$ & $\mathrm{C}-\mathrm{H}$ bending & Alkanes \\
$1475-1375$ & $\mathrm{C}-\mathrm{O}$ stretching & Primary/secondary alcohols \\
$1325-1200$ & $\mathrm{O}-\mathrm{H}$ bending & Esters, ethers, phenols \\
$1175-1150$ & $\mathrm{C}-\mathrm{H}$ bending & alkanes \\
$1000-950$ & $\mathrm{C} \equiv \mathrm{C}$ stretching & Alkynes \\
$900-875$ & - & Aromatic compounds \\
\hline
\end{tabular}

Table. 4. Elemental fatty acid composition of WPPO

\begin{tabular}{lll}
\hline Composition & Chemical name & Percentage \\
\hline C10 & $\begin{array}{l}\text { Aliphatic } \\
\text { compounds }\end{array}$ & 65 \\
C10-C13 & Doxosane & 2.4 \\
C13-C16 & Isoparaffin & 7.5 \\
C16-C20 & 1-hexadecene & 3.1 \\
C20-C23 & Eicosane & 7.6 \\
C23-C30 & Docosane & 15.4 \\
C & & 81.5 \\
H & & 11.3 \\
O & & 7.2 \\
\hline
\end{tabular}

Table 5. List of Equipment used in the experiment

\begin{tabular}{lll}
\hline Property & Equipment & Standard \\
\hline $\begin{array}{l}\text { Kinematic } \\
\text { viscosity }\end{array}$ & SVM 4000 (Anton Paar, UK) & ASTM D445 \\
$\begin{array}{l}\text { Flash point } \\
\begin{array}{l}\text { Oxidation } \\
\text { stability }\end{array}\end{array}$ & NPM 550 (Norma lab, France) & ASTM D93 \\
CP/PP & NTitzerland) 500 (Norma lab, France) & ASTM D2500 \\
$\begin{array}{l}\text { Carbon residue } \\
\text { Total sulfur }\end{array}$ & NMC 440 (Norma lab, France) & ASTM D4530 \\
Calorific value & C 2500 basic calorimeter(IKA, UK) & ASTM D240 \\
Density & SVM 3500 (Anton Paar, UK) & ASTM D1298 \\
\hline
\end{tabular}

Taking into account percentage areas of the spectrum, the highest pick areas of the total chromatography were the following: heptadecane, n-octadecane, n-hexadecane, nonadecane, pentadecane, eicosane, tetradecane and tridecane. Equation 1 shows the effect of linear velocity of the carrier gas in retention time which was used to determine the carrier gas linear velocity.

$$
\operatorname{tr}=(K+1) \mu \frac{(K+1)}{\mu}
$$

Equation 1

Where

$t_{r}$ is the retention time

$\mathrm{L}$ is the column height

$\mathrm{K}$ is the retention factor (constant)

$\mu$ is the carrier gas linear velocity

The components present in the mixed waste plastics pyrolysis fuel ranged from carbon number $\mathrm{C}_{10}$ to $\mathrm{C}_{40}$. A large percentage of these components were made of aliphatic compounds as shown by the results of the GC-MS spectrum analysis shown in Table 4. 


\subsection{WPPO Properties Analysis}

In order to determine the physicochemical properties of the WPPO biodiesel, the characterization was based on the requirements and standards of ASTM D6751. Under this section, the following numbers were calculated using the fatty acid composition and empirical equations [48, 49]. These include the saponification number, the cetane number and the iodine number. The saponification value is as in Equation 2:

$$
S N=\sum \frac{560 \times A_{i}}{M W_{i}}
$$

Equation 2

The iodine value is as according to Equation 3:

$$
I V=\sum \frac{254 \times D \times A_{i}}{M W_{i}}
$$

Equation 3

The cetane index number is calculated based on Equation 4:

$$
C N=46.3+\frac{5458}{S N}-(0.22 \times I V)
$$

Equation 4

Where

$A_{i}$ is the weight percentage of each fatty acid component
$\mathrm{D}$ is the number of double bonds in each fatty acid $\mathrm{MW}_{\mathrm{i}}$ is the molecular weight

To ensure proper mixing, blending and homogenization of the various ratios during the experiment, mixing equipment was used at speeds of $1800 \mathrm{rpm}$ to $2000 \mathrm{rpm}$.

\subsection{Engine Testing and Performance Analysis}

The engine test was conducted on a four-cylinder Iveco diesel dual fuel engine. To help in the analysis of the engine, pressure sensors and crankshaft position sensors and encoders were used. The aim of these sensors was to provide the in-cylinder pressure in relation to the crankshaft position variation. LabVIEW software was used to obtain the combustion data and sketch the graphs.

The engine was coupled to a mechanical dynamometer with idling positions set at $500 \mathrm{rpm}, 1000 \mathrm{rpm}$, as Mode 1, and Mode $21500 \mathrm{rpm}$ and full load at $2000 \mathrm{rpm}$. Figure 2 shows the schematic of the test engine while Table 6 shows the engine specifications.

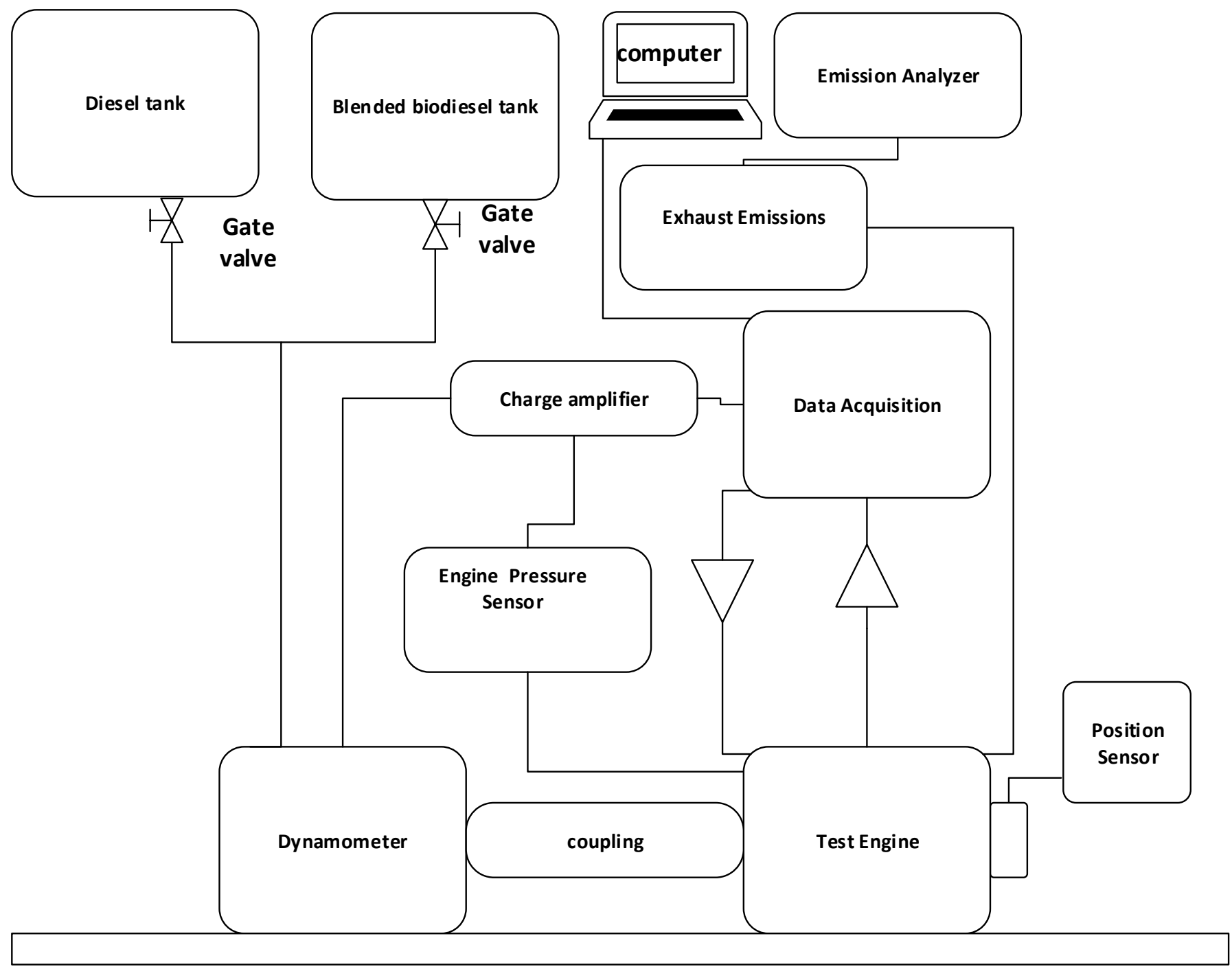

Fig. 2. Schematic diagram of the engine testing and equipment 
International Journal of Engineering Research and Technology. ISSN 0974-3154, Volume 13, Number 10 (2020), pp. 2792-2802

(C) International Research Publication House. https://dx.doi.org/10.37624/IJERT/13.10.2020.2792-2802

Table 6. Experimental engine specifications

\begin{tabular}{ll}
\hline Parameters & Position value \\
\hline Ignition type & 4 (Stroke)DICI \\
Number of cylinders & 4 in-line \\
Cooling medium & Water \\
Manufacturer & Iveco \\
Revolutions per minute & 2000 \\
Brake power & $43.40 \mathrm{~kW} @ 2000$ \\
Cylinder bore & $104 \mathrm{~mm}$ \\
Piston stroke & $115 \mathrm{~mm}$ \\
Compression ratio & $17: 1$ \\
Connecting-rod length & 234 \\
Engine capacity & $2500 \mathrm{cc}$ \\
Dynamometer make & 234 \\
Injection timing & $12 \circ \mathrm{bTDC}$ \\
Maximum torque & $206.9 \mathrm{Nm} @ 1500$ \\
Injection pressure & $250-272 \mathrm{Bar}$ \\
\hline
\end{tabular}

\section{RESULTS AND DISCUSSION}

Table 7. Test fuel biodiesel properties, units of measurement, testing standard methods and the values for PD compared to WPPO

\begin{tabular}{|c|c|c|c|c|}
\hline Property & Unit & PD & WPPO & STANDARD \\
\hline Appearance & - & Clear/brown & Clear/amber & Visual \\
\hline Density@20 @ C & $\mathrm{kg} / \mathrm{M}^{3}$ & 838.8 & 788.9 & ASTM D1298 \\
\hline Kinematic Visc@ $40^{\circ} \mathrm{C}$ & $\mathrm{mm}^{2} / \mathrm{s}$ & 2.32 & 2.17 & ASTM D445 \\
\hline Flash point & ${ }^{0} \mathrm{C}$ & 56.0 & 20.0 & ASTM D93 \\
\hline Cetane index & - & 46 & $65^{\mathrm{a}}$ & ASTM D4737 \\
\hline Hydrogen & $\%$ & 12.38 & 11.77 & ASTM D7171 \\
\hline $\mathrm{Cu}$ corrosion & $3 \mathrm{hrs} @ 100^{\circ} \mathrm{C}$ & - & $1 \mathrm{~B}$ & ASTM D130 \\
\hline Carbon & $\%$ & 74.99 & 79.60 & ASTM D7662 \\
\hline Oxygen & $\%$ & 12.45 & 7.83 & ASTM D5622 \\
\hline Sulphur content & $\%$ & $<0.0124$ & 0.15 & ASTM D4294 \\
\hline IBP temperature & ${ }^{0} \mathrm{C}$ & 160 & 119 & ASTM D86 \\
\hline FBP temperature & ${ }^{0} \mathrm{C}$ & 353.5 & 353.5 & ASTM D86 \\
\hline Recovery & $\%$ & & 98 & - \\
\hline Residue and loss & $\%$ & & 2.0 & - \\
\hline Gross calorific value & $\mathrm{MJ} / \mathrm{kg}$ & 44.84 & $42.15^{\mathrm{b}}$ & ASTM D4868 \\
\hline
\end{tabular}




\subsection{Carbon Monoxide (CO)}

Fig. 3 is a variation of $\mathrm{CO}$ with two engine load modes (Mode 1 , and Mode 2) with a speed range of $500 \mathrm{rpm}$ to $2000 \mathrm{rpm}$. The graph reveals that as the engine load and the blend ratio increased $\mathrm{CO}$ emissions decreased up to $1500 \mathrm{rpm}$ (Mode 2, 75 $\%$ of engine idling load). This was for PD and all blends 95/WPPO5, 90/WPPO10, 80/WPPO20, 70/WPPO30, and 60/WPPO40; the values were 270 ppm, 285 ppm, 315 ppm, 345 ppm, $370 \mathrm{ppm}$, and $385 \mathrm{ppm}$ respectively. The highest value of $\mathrm{CO}$ emission reported was 485 ppm for blend 60/WPPO40 and the lowest value reported was for blend 95/WPPO5 at $388 \mathrm{ppm}$.

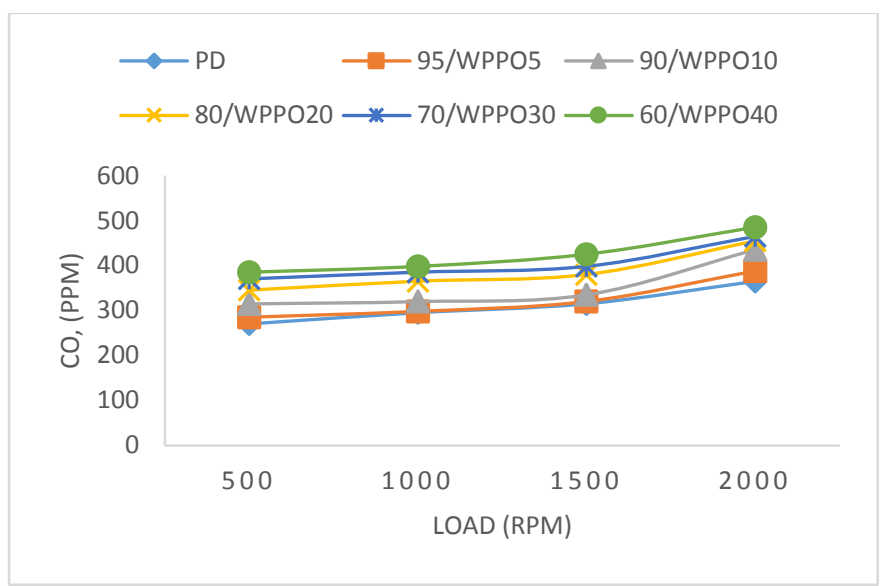

Fig. 3. Carbon monoxide versus load

Another observation is that as the engine was approaching full load (Mode 2, $2000 \mathrm{rpm}$ ), all the test fuels showed increased CO emissions with blends 95/WPPO5 and 90/WPPO10 reporting the lowest emissions value of $388 \mathrm{ppm}$ and $435 \mathrm{ppm}$ among the test blends across the entire engine load Modes 1 and 2 conditions. However, as the load increased from Mode 1 ( $25 \%$ engine idling speed) to Mode 2 (75\% engine speed) the values reported were $320 \mathrm{ppm}$ and $335 \mathrm{ppm}$ respectively.

There are a number of factors, which explain the low $\mathrm{CO}$ emissions as the engine idling load increases. The reason the blends show decreasing and increasing trends in Modes 1 and 2 respectively is due to the high viscosity in WPPO. Viscosity affects the spray pattern hence resulting in poor fuel mixing hence incomplete combustion and increased emissions [50]. This phenomenon is linked to increased engine idling load and short ignition delay, hence increasing $\mathrm{CO}$ emissions. Additionally, the decrease in $\mathrm{CO}$ emissions could also be due to the conversion of $\mathrm{CO}$ to $\mathrm{CO}_{2}$ taking up this reaction from the high oxygen content of biodiesel [51].

\subsection{Unburnt Hydrocarbons (UHC)}

Fig. 4 is a variation of UHC emission with engine load. As the engine load was increased, the UHC emissions increased too. The higher hydrocarbon emissions may have been due to hydrogen radicals in the PD-WPPO blends. However, the increase was more significant when the engine load was in intermediate loads Mode 2, $1500 \mathrm{rpm}$ to $2000 \mathrm{rpm}$ full load (75 $\%$ and $100 \%$ ).
For example, at Mode 1 (500 rpm -1000 rpm, $50 \%$ engine load), the blend values were 22 ppm, 21 ppm, 20 ppm, 18 ppm, and $15 \mathrm{ppm}$ respectively. Compared to full load Mode 2 (1500 rpm to $2000 \mathrm{rpm}$ ) with $35 \mathrm{ppm}, 34 \mathrm{ppm}, 32 \mathrm{ppm}, 29 \mathrm{ppm}$, and 26 ppm (for blends 95/WPPO5, 90/WPPO10, 80/WPPO20, 70/WPPO30, and 60/WPPO40). This leads to the conclusion that at high engine loads the values of UHC emissions are significantly higher for all the blends of WPPO, although still comparatively low when compared to PD fuel.

The UHC emissions from the blends 95/WPPO5 and 90/WPPO10 reported higher values although the trends in Fig.4 show low values compared to the values of PD test fuel. However, the general trend in Fig. 4 shows that increased blend ratio significantly reduced UHC emissions across all the test fuels irrespective of the engine Mode 1 and 2 load conditions. This reduction is due to the high oxygen of WPPO, which has an oxygen content of 7.83 as seen in Table 7.

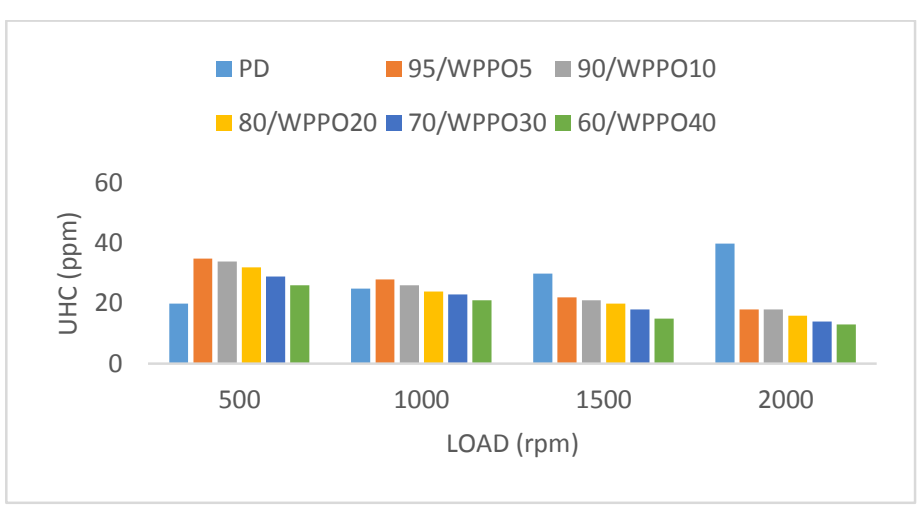

Fig. 4. Unburnt hydrocarbons versus load

\subsection{Oxides of Nitrogen $(\mathrm{NO} x)$}

Fig. 5 is a variation of engine idling load with $\mathrm{NO}_{\mathrm{X}}$ emissions. The figure shows that as the engine idling load was increased there was an increase in the $\mathrm{NO}_{\mathrm{X}}$ emissions irrespective of fuel blend ratio. The values of $\mathrm{NO}_{\mathrm{X}}$ emissions for the blends 95/WPPO5, 90/WPPO10, and 80/WPPO20 reported higher values at Mode , (75 \% load) compared to Mode 1. For example, at $1500 \mathrm{rpm}$ the values of the blends were $335 \mathrm{ppm}$, $358 \mathrm{ppm}$, and $475 \mathrm{ppm}$, compared to PD fuel at $300 \mathrm{ppm}$.

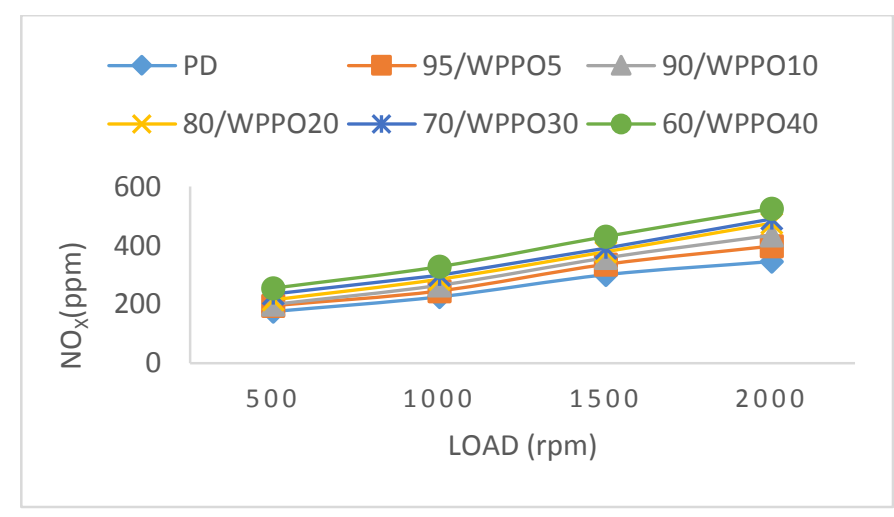

Fig. 5. Oxides of nitrogen emissions versus different engine idling speeds 
Blends 70/WPPO30 and 60/WPPO40 had the highest $\mathrm{NO}_{\mathrm{X}}$ emissions compared to the other blends of 95/WPPO5, 90/WPPO10, and 80/WPPO20 across all the engine load conditions tested. At $500 \mathrm{rpm}$ idling (Mode 1), the two blends (70/WPPO30, 60/WPPO40) had values of $235 \mathrm{ppm}$ and 255 ppm respectively. However, at full speed (2000 rpm, Mode 2) the $\mathrm{NO}_{\mathrm{X}}$ emissions for the two blends increased to $490 \mathrm{ppm}$ and $525 \mathrm{ppm}$ respectively compared to blends 95/WPPO5 for the same idling load (500 rpm, Mode 1) at $175 \mathrm{ppm}$ and at full load (2000 rpm, Mode 2) at $345 \mathrm{ppm}$.

As the blend ratio in Fig. 5 increased, there was a direct increase in emissions of $\mathrm{NO}_{\mathrm{X}}$ across all the blended fuels. However, blend 95/WPPO5 and 90/WPPO10 reported the lowest values of $175 \mathrm{ppm}$ and $195 \mathrm{ppm}$ of $\mathrm{NO}_{\mathrm{X}}$ emissions compared to all the other blends tested. The formation of $\mathrm{NO}_{\mathrm{X}}$ in biodiesel fuel combustion strongly depends on the combustion temperatures and the oxygen concentration in the combustion zone. The high blend ratios of 80/WPPO20, 70/WPPO30, and 60/WPPO40 showed a shortened combustion process hence a poor cooling effect and failure to decrease peak combustion temperatures leading to increased $\mathrm{NO}_{\mathrm{X}}$. WPPO blends emitted higher $\mathrm{NOx}$ due the higher cetane index compared to biodiesel. High cetane index number fuels have a shorter ignition delay which means longer residence time at elevated chamber temperatures, hence higher $\mathrm{NO}_{\mathrm{X}}$ compared to $\mathrm{PD}$.

The increased $\mathrm{NO}_{\mathrm{X}}$ emissions could be a result of the presence of increased cetane index $[52,53]$ and other contaminants from the WPPO biodiesel impurities. Additionally, it could be due to the generation of radicals of hydrocarbon through molecular unsaturation in the blends being identical to the findings of [54, 55]. The final factor could be the increased chamber temperature, which improves combustion but increases NOx emissions, linked to the high oxygen content and the air fuel ratio [49].

\subsection{Brake Thermal Efficiency (BTE)}

The BTE variations with engine load were as shown in Fig. 6. The graphs show that, as the load increased there was an increase in the BTE across all the test fuel blends of WPPO and PD. The results of this experiment show that the BTE increased as the load increased, explained by the reduction in the heat loss as the engine power (more fuel) increased with load. At Mode 1 (1000 rpm, $50 \%$ engine load) the values for blends 95/WPPO5, 90/WPPO10, 80/WPPO20, 70/WPPO30, 60/WPPO40 and PD were $22 \%, 21 \%, 20 \%, 18 \%, 16.5 \%$ and $22.5 \%$ respectively. As the blend ratio and engine idling load increased, there was an increase in BTE across the blends of WPPO but a decrease in the BTE within the blends. For example, at Mode 1 (500 rpm, $25 \%$ engine load), 95/WPPO5 had values of $14 \%, 22 \%, 26.5 \%$ and $25.7 \%$ compared to 80/WPPO20 with $12.5 \%, 20 \%, 22.5 \%$ and $23 \%$ respectively.

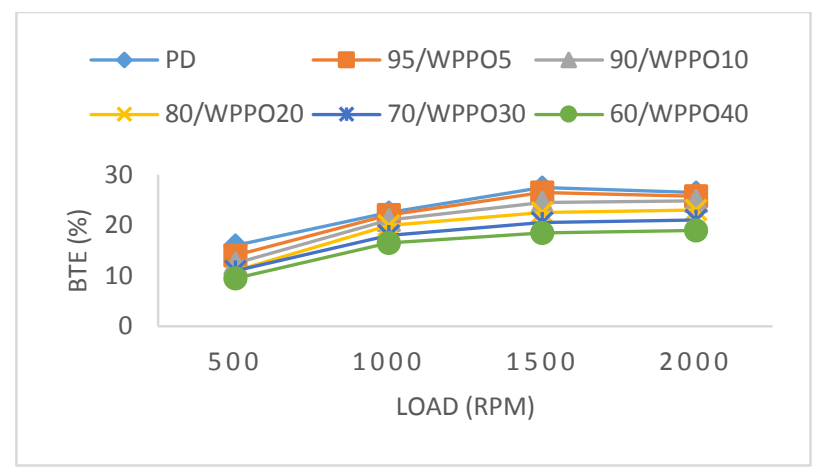

Fig. 6. Brake thermal efficiency versus load

The highest BTE value was $24.5 \%$ by blend 95/WPPO5 at $1500 \mathrm{rpm}$ (Mode 2, $25 \%$ engine load) compared to any other blend of WPPO. Fig. 6 shows values of $24.8 \%, 23 \%, 21 \%$ and $19 \%$ for full speed (2000 rpm, Mode 2) respectively for blends 90/WPPO10, 80/WPPO20, 70/WPPO30, and 60/WPPO40. However, blend 60/WPPO40/E25 reported the lowest values compared to the other blends. At $500 \mathrm{rpm}$ (Mode $1,25 \%$ engine load), the BTE value was $9.5 \%$ compared to 19 $\%$ at full load (2000 rpm, Mode 2), these two being the lowest values of BTE as shown in Fig. 6 for all the blends tested.

\subsection{Brake Specific Fuel Consumption (BSFC)}

Fig. 7 is a variation of BSFC with engine load. The BSFC compared to the engine load in Fig. 7 shows that, as the load increased there was an equal increase in the fuel consumed by the test engine. The values obtained at full engine load for the blends of 95/WPPO5, 90/WPPO10, and 80/WPPO20, 70/WPPO30, 60/WPPO40 and PD were $0.04 \mathrm{~g} / \mathrm{kW} . \mathrm{h}$, $0.041 \mathrm{~g} / \mathrm{kW} . \mathrm{h}, 0.042 \mathrm{~g} / \mathrm{kW} . \mathrm{h}, 0.043 \mathrm{~g} / \mathrm{kW} . \mathrm{h}$ and $0.035 \mathrm{~g} / \mathrm{kW} . \mathrm{h}$ respectively.

At high engine loads the conversion of heat energy to mechanical energy increases with increase in combustion temperature, leading to increased BSFC for the biodiesel. This increase was proportional to the difference in their heating values, which is identical to the findings of [56]. Additionally, the WPPO blends had high densities, therefore suffered high mass injection pressure, hence the increase in BSFC which is identical to studies by $[57,58]$. WPPO blends compare well to conventional diesel fuel and sometimes other biodiesel blends with comparative differences in the heating values.

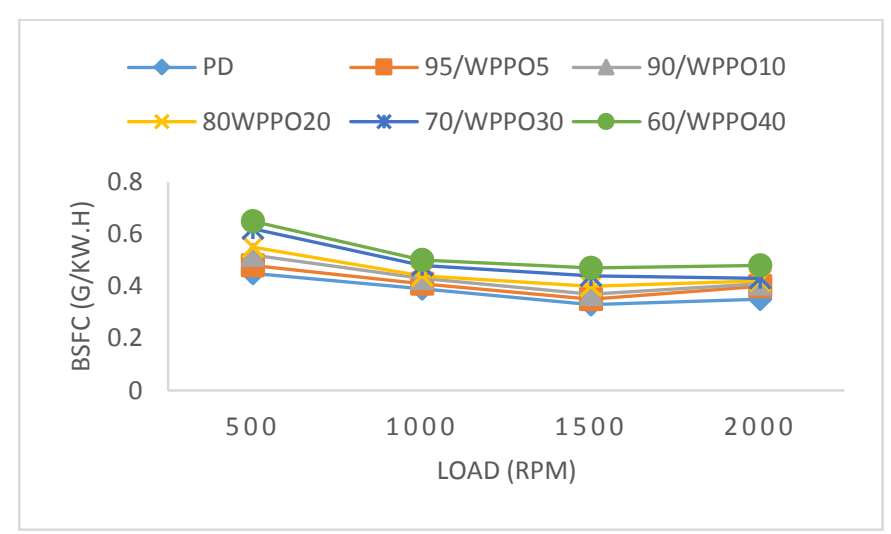

Fig.7. Brake specific fuel consumption versus load 
As the blend ratio increased there was a decrease in the BSFC across all the test fuels. However, the values for all WPPO blends increased compared to PD test fuel. This is due to the lower calorific values of the blends as the percentage of the blend ratio increased. In other words, by increasing the ratio of WPPO in the diesel test fuel, the engine fuel consumption increased, which is identical to the studies of [59-61]. The closeness of the values and the packed graph reveal a close resemblance and identical BSFC characteristics of WPPO to PD properties. For example, at Mode 1 (500 rpm to $1000 \mathrm{rpm}$ ) $50 \%$ engine idling load blend 90/WPPO10 had a value of 0.48 $\mathrm{g} / \mathrm{kW}$.h and $0.43 \mathrm{~g} / \mathrm{kW} . \mathrm{h}$ compared to full engine speed Mode 2 (2000 rpm) load with $0.37 \mathrm{~g} / \mathrm{kW} . \mathrm{h}$ and $0.41 \mathrm{~g} / \mathrm{kW} . \mathrm{h}$. This value is higher than PD test fuel with $0.04 \mathrm{~g} / \mathrm{kW}$.h at $50 \%$ engine load and $0.035 \mathrm{~g} / \mathrm{kW} . \mathrm{h}$ at full engine load.

\subsection{WPPO COMBUSTION ANALYSIS}

Due to the high cetane index of WPPO biodiesel the combustion, process starts early compared to $\mathrm{PD}$, hence higher release than PD fuel combustion. This leads to a higher cylinder peak pressure for WPPO biodiesel fuel compared to PD fuel. Figure 8 shows a comparison of WPPO blends with PD in Mode 1 idling loads of speeds $500 \mathrm{rpm}$ to $1000 \mathrm{rpm}$. Under this condition, WPPO blends in Mode 1 exhibited higher peak cylinder pressure compared to PDF, which is evident as the blend ratio increased as in Figure 8.

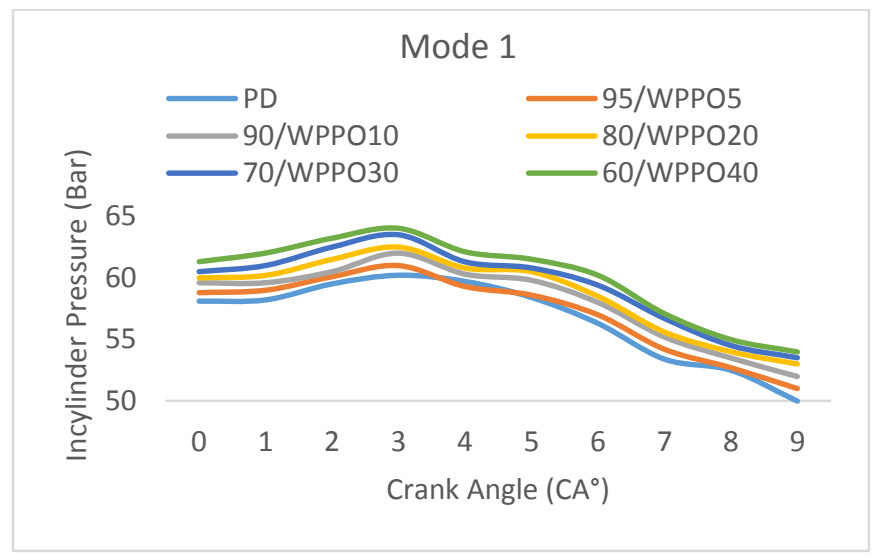

Fig. 8. In-cylinder pressure vs. crank angle variation compared to diesel and WPPO

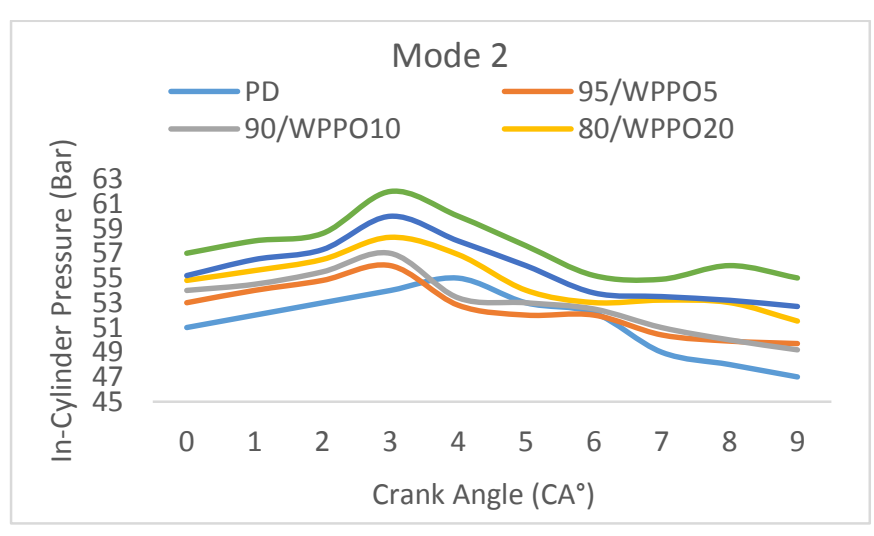

Fig. 9. In-cylinder pressure vs. crank angle variation compared to diesel and WPPO in Mode 2
Compared to when the engine is running at high speed (high load), low speed (low load idling) residual gas temperatures and engine wall temperatures are low [62]. In other words, injection pressure and fuel temperature are low hence the increased delay. This is the explanation of why diesel in the combustion analysis starts after $3^{\circ}$ CA compared to WPPO biodiesel blends. This makes diesel fuel reach a peak cylinder pressure further after top dead center in the power stroke. On the other hand, biodiesel blends reaches peak cylinder pressure early before top dead center in the power stroke. For example, in Figure 9 Mode 2 speed, the values of peak cylinder pressure for PD fuel is 55 bar compared to 56 bar for WPPO blend 95/WPPO5. This is due to the enhanced combustion resulting from rapid combustion of the biodiesel blends at the pre-mixed phase. Of all the test fuels, PD fuel had the lowest peak cylinder pressure, which occurs slightly after top dead center [63].

\section{REFERENCES}

[1] Mofijur M, Masjuki HH, Kalam MA, Atabani AE, Shahabuddin M, Palash SM, Hazrat MA (2013) Effect of biodiesel from various feedstocks on combustion characteristics, engine durability and materials compatibility: A review. Renewable Sustainable Energy Rev. 24 https://doi.org/10.1016/j.rser.2013.07.051

[2] Mofijur M., Masjuki HH, Kalam MA, Hazrat MA, Liaquat A., Shahabuddin M, and Varman M (2012). Prospects of biodiesel from Jatropha in Malaysia. Renewable Sustainable Energy Rev. 16: 5007-5020.

[3] Rahman S A, Masjuki H, Kalam M, Abedin M, Sanjid A, Rahman, MM (2014). Assessing idling effects on a compression ignition engine fueled with Jatropha and Palm biodiesel blends. Renewable Energy. https://doi.org/10.1016/j.renene.2014.02.050

[4] Eurostatistics (2017) Environmental tax statistics. Available: http://epp.eurostat.ec.europa.eu/statistics _explained /index.php/Environmental_tax_statistics. Accessed 24/08/2019

[5] Palash S, Kalam M, Masjuki H, Masum B, Fattah IR, Mofijur M (2013) Impacts of biodiesel combustion on NOx emissions and their reduction approaches. Renewable Sustainable Energy Rev. https://doi.org/10.1016/j.rser.2013.03.003

[6] Chisti Y, Biodiesel from microalgae (2007) Biotechnol. Adv. https://doi.org/10.1016/j.biotechadv.2007.02.001

[7] Phan AN, Phan TM (2008) Biodiesel production from waste cooking oils. Fuel. https://doi.org/10.1016/j.fuel. 2008.07.008

[8] Huang G, Chen F, Wei D, Zhang X, Chen G (2010) Biodiesel production by microalgal biotechnology. Appl. Energy. https://doi.org/10.1016/j.apenergy.2009.06.016

[9] Maroa S, Inambao F (2018) Influence of exhaust gas recirculation and emission characteristics of a diesel engine using pyrolyzed waste plastic biodiesel and blends. Int. J. Appl. Eng. Res. 13: 8321-8335. 
International Journal of Engineering Research and Technology. ISSN 0974-3154, Volume 13, Number 10 (2020), pp. 2792-2802

(C) International Research Publication House. https://dx.doi.org/10.37624/IJERT/13.10.2020.2792-2802

[10] Mani M, Nagarajan G, Sampath S (2011) Characterisation and effect of using waste plastic oil and diesel fuel blends in compression ignition engine. Energy. https://doi.org/10.1016/j.energy.2010.10.049

[11] Lee S, Yoshida K, Yoshikawa K (2015) Application of waste plastic pyrolysis oil in a direct injection diesel engine: For a small scale non-grid electrification. Energy Environ. Res. DOI:10.5539/eer.v5n1p18

[12] Rahman S A, Masjuki H, Kalam M, Abedin M, Sanjid A, Imtenan S (2014). Effect of idling on fuel consumption and emissions of a diesel engine fueled by Jatropha biodiesel blends J. Cleaner Prod. https://doi.org/10.1016/j.jclepro.2014.01.048

[13] Jayed M, Masjuki HH, Saidur R, Kalam M, Jahirul MI (2009). Environmental aspects and challenges of oilseed produced biodiesel in Southeast Asia. Renewable Sustainable Energy Rev. https://doi.org/10.1016/j.rser.2009.06.023

[14] Liaquat A, Kalam M, Masjuki H, Jayed M (2010) Potential emissions reduction in road transport sector using biofuel in developing countries. Atmos. Environ. https://doi.org/10.1016/j.atmosenv.2010.07.003

[15] Demirbas A (2008) Biodiesel: a realistic fuel alternative for diesel engines. Springer, London.. DOI:10.1007/978$1-84628-995-8$

[16] Candeia R, Silva M, Carvalho Filho J, Brasilino M, Bicudo T, Santos I. et al (2009) Influence of soybean biodiesel content on basic properties of biodiesel-diesel blends. Fuel. https://doi.org/10.1016/j.fuel.2008.10.015

[17] Singh SP, and Singh D (2010) Biodiesel production through the use of different sources and characterization of oils and their esters as the substitute of diesel: A review. Renewable Sustainable Energy Rev. https://doi.org/10.1016/j.rser.2009.07.017

[18] Jain S, Sharma MP (2011) Oxidation stability of blends of Jatropha biodiesel with diesel. Fuel. https://doi.org/10.1016/j.fuel.2011.05.003

[19] Maroa S, Inambao F (2019) The effect of cetane number and oxygen content in the performance and emissions characteristics of a diesel engine using biodiesel blends. J. Energy Southern Africa. DOI:10.17159/24133051/2019/v30i2a5337

[20] Hussan MJ, Hassan MH, Kalam MA, emon LA (2013) Tailoring key fuel properties of diesel-biodiesel-ethanol blends for diesel engine. J. Cleaner Prod. https://doi.org/10.1016/j.jclepro.2013.01.023

[21] Fazal M, Haseeb A, Masjuki H (2011) Biodiesel feasibility study: An evaluation of material compatibility; performance; emission and engine durability. Renewable Sustainable Energy Rev. https://doi.org/10.1016 /j.rser.2010.10.004

[22] Xue J, Grift TE, Hansen AC (2011) Effect of biodiesel on engine performances and emissions. Renewable Sustainable Energy Rev. https://doi.org/10.1016/j .rser.2010.11.016

[23] Atabani A, Silitonga A, Ong H, Mahlia T, Masjuki H, Badruddin IA et al 2013) Non-edible vegetable oils: A critical evaluation of oil extraction, fatty acid compositions, biodiesel production, characteristics, engine performance and emissions production. Renewable Sustainable Energy Rev. https://doi.org/10.1016/j.rser.2012.10.013

[24] Naima K, Liazid A (2013) Waste oils as alternative fuel for diesel engine: a review. J. Petrol Technol Alternative Fuels. DOI:10.5897/JPTAF12.026

[25] Kaimal VK, Vijayabalan P (2015) A detailed study of combustion characteristics of a DI diesel engine using waste plastic oil and its blends. Energy Convers Manage. https://doi.org/10.1016/j.enconman.2015.08.043

[26] Ananthakumar S, Jayabal S, Thirumal P (2017) Investigation on performance, emission and combustion characteristics of variable compression engine fuelled with diesel, waste plastics oil blends. Journal of the Brazilian Society of Mechanical Sciences and Engineering. https://doi.org/10.1007/s40430-016-0518-6

[27] Roy MM, Wang W, Bujold J (2013) Biodiesel production and comparison of emissions of a DI diesel engine fueled by biodiesel-diesel and canola oil-diesel blends at high idling operations. Appl. Energy. https://doi.org/10.1016/j.apenergy.2013.01.057

[28] Rahman SA, Masjuki H, Kalam M, Abedin M, Sanjid A, Sajjad H (2013) Production of palm and Calophyllum inophyllum based biodiesel and investigation of blend performance and exhaust emission in an unmodified diesel engine at high idling conditions. Energy Conserv. Manage. https://doi.org/10.1016/j.enconman.2013.07 .061

[29] Lambert DC, Vojtisek-Lom M, Wilson PJ (2002) Roadside emissions study-preliminary results for stationary and on-road testing of diesel trucks in Tulare, CA. Clean Air Technologies International, Inc. in cooperation with California Air Resource Board, Mobile Source Operations Division.

[30] Calcagno JA (2005) Evaluation of heavy-duty diesel vehicle emissions during cold-start and steady-state idling conditions and reduction of emissions from a truckstop electrification program. $\mathrm{PhD}$ dissertation, University of Tenessee, Knoxville.

[31] Zietsman J, Villa JC, Forrest TL, Storey JM (2005). Mexican truck idling emissions at the El Paso-Ciudad Juarez border location. Available: https://trid.trb.org/view/775622. Accessed 15/08/2019)

[32] Khan AS, Clark NN, Thompson GJ, Wayne WS, Gautam M, Lyon DW et al (2006) Idle emissions from heavy-duty diesel vehicles: review and recent data. J. Air Waste Manag. Assoc. https://doi.org/10.1080/10473289 .2006 .10464551

[33] Roy MM, Calder J, Wang W, Mangad A, Diniz FCM 
(2016) Cold start idle emissions from a modern Tier-4 turbo-charged diesel engine fueled with diesel-biodiesel, diesel-biodiesel-ethanol, and diesel-biodiesel-diethyl ether blends. Appl. Energy. https://doi.org/10.1016 /j.apenergy.2016.07.090

[34] Chaichan MT (2014). Experimental study of the effect of exhaust gas recirculation (EGR) and injection timing on emitted emissions at idle period. Al-Khwarizmi Eng. J. 10: 33-44.

[35] Shancita I, Masjuki H, Kalam M, Fattah IR, Rashed M, Rashedul H (2014). A review on idling reduction strategies to improve fuel economy and reduce exhaust emissions of transport vehicles. Energy Conserve. Manage.

https://doi.org/10.1016/j.enconman.2014.09.036

[36] Chin J-Y, Batterman SA, Northrop WF, Bohac SV, Assanis DN (2012). Gaseous and particulate emissions from diesel engines at idle and under load: comparison of biodiesel blend and ultralow sulfur diesel fuels. Energy Fuels. https://doi.org/10.1021/ef300421h

[37] Storey JMT, Lewis JF, Dam SA, Edwards TQ, DeVault KD, Retrossa GL, and Dominic J (2003) Particulate matter and aldehyde emissions from idling heavy-duty diesel trucks. SAE Technical Paper, Warrendale, Pennsylvania 0148-7191, 2003. https://doi.org /10.4271/2003-01-0289

[38] Brodrick C-J, Dwyer HA, Farshchi M, Harris DB, King Jr FG (2002) Effects of engine speed and accessory load on idling emissions from heavy-duty diesel truck engines. J. Air Waste Manage. Assoc. https://doi.org/10.1080/10473289.2002.10470838

[39] Gaines L, Vyas A, Anderson JL (2006) Estimation of fuel use by idling commercial trucks. Transp. Res. Rec. https://doi.org/10.1177/0361198106198300113

[40] Denning C, Camille K. 2010. The good haul: innovations that improve freight transportation and protect the environment. Available https://trid.trb.org/view/914909. Accessed 20/08/2019

[41] Carrico AR, Padgett P, Vandenbergh MP, Gilligan J, Wallston KA (2009) Costly myths: an analysis of idling beliefs and behavior in personal motor vehicles. Energy Policy. https://doi.org/10.1016/j.enpol.2009.03.031

[42] Nitschke B, Wagner F, Anderson M, Slezak L (2003). Idle reduction technology demonstration plan (No. NREL/TP-540-33629). National Renewable Energy Lab (NREL), Golden, Colorado, United States.

[43] Lapuerta M, Armas O, Rodriguez-Fernandez J (2008) Effect of biodiesel fuels on diesel engine emissions. Prog. Energy Combust. https://doi.org/10.1016/j.pecs.2007.07.001

[44] Lapuerta M, Rodríguez-Fernández J, Agudelo JR (2008) Diesel particulate emissions from used cooking oil biodiesel. Bioresour. Technol. https://doi.org/10.1016/j.biortech.2007.01.033
[45] Bhale PV, Deshpande NV, Thombre SB (2009) Improving the low temperature properties of biodiesel fuel. Renewable Energy. https://doi.org/10.1016/j .renene.2008.04.037

[46] Cetinkaya M, Ulusoy Y, Tekìn Y, Karaosmanoğlu F (2005) Engine and winter road test performances of used cooking oil originated biodiesel. Energy Conserv. Manage.

https://doi.org/10.1016/j.enconman.2004.06.022

[47] Inambao F, Maroa S (2019). The production of pyrolysis oil from waste plastic and other solid waste biomass design, fabrication and evaluation. African And International Domestic Use Of Energy Conference, Cape Town, 2019.

[48] Azam MM, Waris A, Nahar N (2005) Prospects and potential of fatty acid methyl esters of some nontraditional seed oils for use as biodiesel in India. Biomass Bioenergy. https://doi.org/10.1016/j.biombioe.2005.05.001

[49] Devan P, Mahalakshmi N (2009) A study of the performance, emission and combustion characteristics of a compression ignition engine using methyl ester of paradise oil-eucalyptus oil blends. Appl. Energy. DOI: 10.1016/j.apenergy.2008.07.008

[50] Ghurri A, Kim J-D, Kim HG, Jung J-Y, Song K-K (2012). The effect of injection pressure and fuel viscosity on the spray characteristics of biodiesel blends injected into an atmospheric chamber. J. Mech. Sci. Technol. https://doi.org/10.1007/s12206-012-0703-1

[51] Rahman MM, Hassan MH, Kalam MA, Atabani AE, Memon LA, Rahman SA (2014) Performance and emission analysis of Jatropha curcas and Moringa oleifera methyl ester fuel blends in a multi-cylinder diesel engine. J. Cleaner Prod. https://doi.org/10.1016 /j.jclepro.2013.08.034

[52] Hoekman SK, Broch A, Robbins C, Ceniceros E, Natarajan M (2012). Review of biodiesel composition, properties, and specifications. Renewable Sustainable Energy Rev. https://doi.org/10.1016/j.rser.2011.07.143

[53] Robbins C, Hoekman SK, Gertler A, Broch A, Natarajan M (2009) Biodistillate transportation fuels 2.-Emissions impacts. SAE Technical Paper 0148-7191. https://doi.org/10.4271/2009-01-2724

[54] Benjumea P, Agudelo JR, Agudelo AF (2010). Effect of the degree of unsaturation of biodiesel fuels on engine performance, combustion characteristics, and emissions. Energy Fuels. https://doi.org/10.1021/ef101096x

[55] Altun Ş (2014) Effect of the degree of unsaturation of biodiesel fuels on the exhaust emissions of a diesel power generator. Fuel. https://doi.org/10.1016/j.fuel .2013.09.028

[56] Lapuerta M, Armas O, Hernández JJ, Tsolakis A (2010) Potential for reducing emissions in a diesel engine by fuelling with conventional biodiesel and Fischer-Tropsch 
diesel. Fuel. https://doi.org/10.1016/j.fuel.2010.05.013

[57] Tüccar G, Tosun E, Özgür T, Aydın K (2014). Diesel engine emissions and performance from blends of citrus sinensis biodiesel and diesel fuel. Fuel. https://doi.org/10.1016/j.fuel.2014.04.065

[58] Raheman H, Ghadge SV (2007) Performance of compression ignition engine with mahua (Madhuca indica) biodiesel. Fuel. https://doi.org/10.1016 /j.fuel.2007.02.019

[59] Armas O, Yehliu K, Boehman AL (2010) Effect of alternative fuels on exhaust emissions during diesel engine operation with matched combustion phasing. Fuel. https://doi.org/10.1016/j.fuel.2009.09.022

[60] Godiganur S, Murthy CS, Reddy RP (2010) Performance and emission characteristics of a Kirloskar HA394 diesel engine operated on fish oil methyl esters. Renewable Energy. https://doi.org/10.1016/j.renene.2009.07.007

[61] Zhu L, Zhang W, Liu W, Huang Z (2010) Experimental study on particulate and NOx emissions of a diesel engine fueled with ultra low sulfur diesel, RME-diesel blends and PME-diesel blends. Sci. Total Environ. https://doi.org/10.1016/j.scitotenv.2009.10.056

[62] Turns SR (1996). An introduction to combustion: concepts and applications, 3rd edn. McGraw-Hill, New Delhi.

[63] Tarabet L, Loubar K, Lounici M, Hanchi S, Tazerout M (2011) Experimental evaluation of performance and emissions of DI diesel engine fuelled with eucalyptus biodiesel. Proceedings of the Internal Combustion Engines: Performance, Fuel Economy and Emissions. IMechE, London, 29-30 November 2011. https://doi.org/10.1533/9780857095060.5.167 